\title{
Prevalence and epidemiology of chronic hepatitis C among prisoners of Mato Grosso do Sul State, Brazil
}

Pompilio MA (1), Pontes ERJC (1), Castro ARCM (1), Andrade SMO (1), Stief ACF (1), Martins RMB (2), Mousquer GJ (1), Murat PG (1), Francisco RBL (3), Pompilio SAL (4), Rezende GR (4), Elias-Junior E (5)

(1) Federal University of Mato Grosso do Sul, UFMS, Campo Grande, Mato Grosso do Sul State, Brazil; (2) Federal University of Goiás, UFG, Goiânia, Goiás State, Brazil; (3) Central Laboratory of Public Health, Campo Grande, Mato Grosso do Sul State, Brazil; (4) Anhanguera Education Center-UNIDERP, Campo Grande, Mato Grosso do Sul State, Brazil; (5) São Julião Hospital, Campo Grande, Mato Grosso do Sul State, Brazil.

\begin{abstract}
In Mato Grosso do Sul state, Brazil, the number of prisoners has increased in the recent years and the control of hepatitis $\mathrm{C}$ virus (HCV) has become more complex. The aim of the present study was to estimate the prevalence and identify the genotypes of HCV in prisoners as well as the factors associated with this infectious disease. Thereby, 443 men and 243 women from prisons were interviewed and subjected to blood collection. Anti-HCV reactive samples were analyzed by RT-PCR and genotyped. The overall seroprevalence of HCV infection was $4.8 \%$ (95\%Cl: 3.4 to $6.8 \%)$. Furthermore, the prevalence was higher in: men, injecting drug users, tattooed persons, those who were more than 50 years old, individuals who have been arrested multiple times, people with previous history of sexually transmitted disease (STD), persons who received blood transfusions or those with HIV/AIDS. The prevalence of RNA HCV by PCR was 3.0\% (95\% Cl: 1.7 to 4.2\%). Moreover, the coinfection of HIV and HCV was 33.3\%. In addition, genotype 1 was the most frequent (85\%) followed by genotype 3 (15\%). The screening strategy for HCV and other infectious diseases in inmates is important as it establishes an early diagnosis, opportunity for treatment and allows the breaking of the transmission chain.
\end{abstract}

Key words: hepatitis C, genotype, polymerase chain reaction, epidemiology, prisoners.

\section{INTRODUCTION}

Hepatitis $\mathrm{C}$ virus (HCV) is responsible for the infection of approximately 170 million people worldwide. Incarcerated individuals are particularly affected since they are at higher risk of being infected due to tattooing, piercing and use of injecting drugs (1-8). The living conditions of these people outside and inside prisons contribute to the transmission of infectious diseases. Their lifestyles, combined with worsened drug abuse inside prisons, reflect precarious levels of health care compared to the general population $(3,4)$.

The seroprevalence of hepatitis $\mathrm{C}$ among inmates varies according to local characteristics. A review of previously published international studies has shown a range between 1.5-47.9\% (9-
13). Previous Brazilian studies have demonstrated values from 6.3 to $41 \%$ (14-19).

$\mathrm{HCV}$ is classified into six genotypes and multiple subtypes. This variability has epidemiologic importance and is directly related to diagnosis as well as therapeutic response $(20,21)$.

Genotypes 1, 2 and 3 are more prevalent in Europe, Japan and the United States. Genotype 4 is common in Central Africa, Egypt and Middle East whereas genotype 5 is frequent in South Africa. Lastly, genotype 6 is found in Asia (2123). In Brazil, genotypes 1, 2 and 3 have been identified (being the first more frequent), and presenting distinct distributions throughout the country (24-31).

The aim of the current study was to estimate the prevalence of $\mathrm{HCV}$ as well as to identify the 
factors associated with the infection among prison inmates, therefore determining the circulating genotypes of $\mathrm{HCV}$.

\section{PATIENTS AND METHODS}

In 2009, from a total of 3,418 men and 395 women, a non-probability sample of 686 prisoners was obtained by using an estimated prevalence of $9.6 \%( \pm 2.6)$ for men and 3.6\% $( \pm 2.2)$ for women. It was difficult to have access to all prison pavilions and cells due to security reasons. The total sample size included 443 men and 243 women, with a significance level of 5\%. All individuals were interviewed and their blood samples were collected. The samples were tested by enzyme linked immunosorbent assay (ELISA) and by the immunodot method (rapid test), for the detection of an anti-HCV marker (Bioelisa HCV $4.0^{\circledR}$, BioKit, Spain and ImmunoComb II $\mathrm{HCV}^{\oplus}$ kit, Orgenics, Germany) and anti-HIV (ELISA and Western blot).

Weakly reactive samples to anti-HCV (OD/cutoff $<3.0$ ) were tested again by line immunoassay (INNO-LIA ${ }^{\oplus} \mathrm{HCV}$ Ab III, Innogenetics, Belgium) and anti-HCV positive ones were tested for viral RNA detection by reverse transcriptionpolymerase chain reaction (RT-PCR) with primers complementary to the conserved area of the 5 ' $\mathrm{NC}$ region of HCV, essentially as previously described (32). Positive samples were also submitted to genotyping method by line probe assay (INNO$\mathrm{LiPA}^{\oplus}$, Innogenetics, Belgium) using biotinylated primers complementary to the $5^{\prime} \mathrm{NC}$ region of $\mathrm{HCV}$ genome. To confirm HCV genotypes and subtypes, positive samples were amplified with primers complementary to the region NS5B of $\mathrm{HCV}$ under the same conditions as described by Sandres-Sauné et al. (33). Chi-square, chi-square for trend and Fisher's exact tests were employed for statistical analyses and the prevalence ratios were calculated, with a $95 \%$ confidence interval. In order to estimate adjusted prevalence ratios, the Cox regression was chosen (time interval equal to one unit), and variables of significance less than $5 \%$ were selected. The present study was approved by the Research Ethics Committee of Federal University of Mato Grosso do Sul.

\section{RESULTS}

The overall seroprevalence of HCV infection was $4.8 \%$ (95\%CI: 3.4-6.8\%). Regarding gender, the prevalence was $0.8 \%$ in women $(95 \% \mathrm{CI}: 0.1-$ $2.9 \%$ ) and $7 \%$ in men (95\%CI: 4.9-9.9\%).

$\mathrm{HCV}$ was more prevalent in men, injecting drug users, tattooed individuals or people who had been subjected to blood transfusion as well as individuals coinfected with HIV. Higher prevalence in persons aged 50 years or more, inmates with multiple arrests and with history of sexually transmitted diseases (STDs was significant in the bivariate analysis (Tables 1, 2 and 3).

Only 23 prisoners reported having undergone acupuncture and all of them were anti-HCV negative. History of hemodialysis was reported by two prisoners, none with hepatitis C. Piercing was reported by only two individuals in the anti$\mathrm{HCV}$ positive group.

Among 33 anti-HCV reactive blood samples, 29 were referred for detection of HCV RNA. Through the use of RT-PCR, HCV was detected in 20 blood samples (69\%) therefore the real prevalence of chronic hepatitis in the study sample $(\mathrm{n}=686)$ was $3.0 \%$ (95\%CI: $1.7-4.2 \%)$, being $4.3 \%$ in men (95\%CI: $2.4-6.2 \%)$ and $0.5 \%$ in women (95\%CI: $0.2-0.7 \%)$. Genotype 1 was the most prevalent (85\%) followed by genotype 3 (15\%). Patients with HIV and HCV co-infection showed the following genotypes: 1a (4/8), 1b $(3 / 8)$ and $1(1 / 8)$ (Figure 1).

\section{DISCUSSION}

This investigation is the first study on the epidemiology of HCV infection in Campo Grande, Mato Grosso do Sul State, and has important public health implications. The prevalence of $\mathrm{HCV}$ found among prisoners was higher than that observed in the general population (1.42$1.5 \%)(34,35)$.

The HCV seroprevalence of $4.8 \%$ (95\%CI: 3.4$6.8 \%$ ) was lower than those previously found in incarcerated populations in São Paulo city (34$41 \%)(7,16)$. Nevertheless, the present findings are similar to results obtained in prisoners in the municipality of Manhuaçú, Minas Gerais state (6\%), Ribeirão Preto, São Paulo state (8.7\%), and Salvador, Bahia state $(6.4 \%)(15,18,19)$. In the female incarcerated population of Campo Grande the rate was lower than that found in the Butantã Prison, São Paulo state (16.2\%) (17).

When compared with international studies, the prevalence of $\mathrm{HCV}$ infection among inmates 
Table 1. Distribution of data from prisoners according to factors associated with HCV infection in Campo Grande, Mato Grosso do Sul, Brazil in 2010 ( $n=686)$

\begin{tabular}{|c|c|c|c|c|c|c|}
\hline \multirow[t]{2}{*}{ Variables } & \multicolumn{2}{|c|}{$\begin{array}{c}\text { Anti-HCV + } \\
(n=33)\end{array}$} & \multicolumn{2}{|c|}{$\begin{array}{c}\text { Anti-HCV - } \\
(n=653)\end{array}$} & \multirow[t]{2}{*}{ PR (95\%Cl) } & \multirow{2}{*}{$p$} \\
\hline & $\mathbf{n}$ & $\%$ & $\mathbf{n}$ & $\%$ & & \\
\hline \multicolumn{7}{|c|}{ Gender } \\
\hline Male & 31 & 7.0 & 412 & 93.0 & 1 & (1) $<0.001$ \\
\hline Female & 2 & 0.8 & 241 & 99.2 & $8.50(2.05-35.22)$ & \\
\hline \multicolumn{7}{|c|}{ Age } \\
\hline Above 50 years & 6 & 10.5 & 51 & 89.5 & 1 & (2) $<0.001$ \\
\hline 31 to 50 years & 24 & 7.2 & 311 & 92.8 & $1.47(0.63-3.44)$ & \\
\hline Under 31 years & 3 & 1.0 & 291 & 99.0 & $10.32(2.66-40.06)$ & \\
\hline \multicolumn{7}{|c|}{ Education } \\
\hline Illiteracy & 1 & 3.8 & 25 & 96.2 & 1 & (2) 0.112 \\
\hline Eight years & 28 & 5.8 & 451 & 94.2 & $0.66(0.09-4.65)$ & \\
\hline Above eight years & 4 & 2.2 & 177 & 97.8 & $0.20(0.20-14.98)$ & \\
\hline \multicolumn{7}{|c|}{ HCV knowledge } \\
\hline None & 18 & 4.7 & 404 & 95.3 & 1 & (1) 0.399 \\
\hline Yes & 15 & 5.7 & 249 & 94.3 & $0.75(0.39-1.46)$ & \\
\hline \multicolumn{7}{|c|}{ Number of arrests } \\
\hline Six or more & 5 & 14.7 & 29 & 85.3 & 1 & (2) $<0.001$ \\
\hline Two to five & 24 & 6.8 & 330 & 93.2 & $2.17(0.88-5.32)$ & \\
\hline Once & 4 & 1.3 & 294 & 98.7 & $10.96(3.09-38.86)$ & \\
\hline \multicolumn{7}{|c|}{ Stable relationship } \\
\hline No & 19 & 5.4 & 332 & 94.6 & 1 & (1) 0.450 \\
\hline Yes & 14 & 4.2 & 321 & 95.8 & $1.30(0.66-2.54)$ & \\
\hline \multicolumn{7}{|c|}{ Homosexual relationship } \\
\hline Yes & 6 & 5.1 & 112 & 94.9 & 1 & (1) 0.788 \\
\hline No & 25 & 4.5 & 529 & 95.5 & $1.13(0.47-2.69)$ & \\
\hline No information & 2 & 14.3 & 12 & 85.7 & & \\
\hline \multicolumn{7}{|c|}{ Condom use } \\
\hline Never & 9 & 4.8 & 179 & 95.2 & 1 & (2) 0.458 \\
\hline Sometimes & 15 & 4.2 & 344 & 95.8 & $1.15(0.51-2.57)$ & \\
\hline Always & 9 & 6.9 & 121 & 93.1 & $0.69(0.28-1.69)$ & \\
\hline No information & & - & 9 & 100.0 & - & \\
\hline \multicolumn{7}{|c|}{ STD } \\
\hline Yes & 21 & 9.9 & 192 & 90.1 & 1 & (1) $<0.001$ \\
\hline No & 12 & 2.6 & 450 & 97.4 & $3.80(1.90-7.57)$ & \\
\hline No information & & - & 11 & 100.0 & - & \\
\hline
\end{tabular}

PR: prevalence ratio; if $p \leq 0.05$, there is significant statistical difference between values; blank information was excluded; ${ }^{(1)}$ chisquare test; ${ }^{(2)}$ chi-square for trend test. 
Table 2. Distribution of data from prisoners according to other factors associated with HCV, Campo Grande, Mato Grosso do Sul, Brazil in $2010(n=686)$

\begin{tabular}{|c|c|c|c|c|c|c|}
\hline \multirow[t]{2}{*}{ Variables } & \multicolumn{2}{|c|}{$\begin{array}{c}\text { Anti-HCV + } \\
(n=33)\end{array}$} & \multicolumn{2}{|c|}{$\begin{array}{c}\text { Anti-HCV - } \\
(n=653)\end{array}$} & \multirow[t]{2}{*}{ PR $(95 \% \mathrm{Cl})$} & \multirow{2}{*}{$p$} \\
\hline & $\mathrm{n}$ & $\%$ & $\mathrm{n}$ & $\%$ & & \\
\hline \multicolumn{7}{|c|}{ Injecting drug use } \\
\hline Yes & 18 & 24.7 & 55 & 75.3 & 1 & (2) $<0.001$ \\
\hline No & 15 & 2.6 & 562 & 97.4 & $9.48(5.00-18.00)$ & \\
\hline No information & & - & 36 & 100.0 & - & \\
\hline \multicolumn{7}{|c|}{ Blood transfusion } \\
\hline Yes & 12 & 10.5 & 102 & 89.5 & 1 & (1) 0.001 \\
\hline No & 20 & 3.5 & 545 & 96.5 & $2.97(1.50-5.91)$ & \\
\hline No information & 1 & 14.3 & 6 & 85.7 & - & \\
\hline \multicolumn{7}{|c|}{ Tattoos } \\
\hline Yes & 25 & 6.3 & 372 & 93.7 & 1 & (1) 0.033 \\
\hline No & 8 & 2.8 & 281 & 97.2 & $2.27(1.04-4.97)$ & \\
\hline \multicolumn{7}{|c|}{ HIV/AIDS } \\
\hline Yes & 11 & 32.4 & 23 & 67.6 & 1 & (2) $<0.001$ \\
\hline No & 22 & 3.4 & 630 & 96.6 & $9.59(5.07-18.12)$ & \\
\hline
\end{tabular}

PR: prevalence ratio; if $p \leq 0.05$, there is significant statistical difference between values; blank information was excluded; ${ }^{(1)}$ chisquare test; ${ }^{(2)}$ Fisher's exact test.

Table 3. Variables analyzed by multivariate analysis on the prevalence of HCV among inmates in Campo Grande, Mato Grosso do Sul, Brazil in 2010

\begin{tabular}{c|c|c|c}
\hline Variables & $\mathbf{p}$ & $\begin{array}{c}\text { Prevalence ratio } \\
\text { (PR) }\end{array}$ & $95 \% \mathrm{Cl}(\mathrm{PR})$ \\
\hline Age & 0.828 & 1.14 & $0.33-3.92$ \\
\hline History of STD & 0.595 & 1.49 & $0.34-6.49$ \\
\hline Number of arrests & 0.250 & 1.68 & $0.70-4.04$ \\
\hline Tattoos & 0.019 & 3.46 & $2.80-7.24$ \\
\hline Blood transfusion & 0.003 & 3.59 & $1.54-8.38$ \\
\hline Gender & $<0.001$ & 7.28 & $1.60-33.16$ \\
\hline Injecting drug use & $<0.001$ & 10.41 & $4.98-19.15$ \\
\hline HIV/AIDS & $<0.001$ & 10.86 & $5.04-19.55$ \\
\hline
\end{tabular}

Cox regression: if $p \leq 0.05$, then there is significant statistical difference between variables categories. 


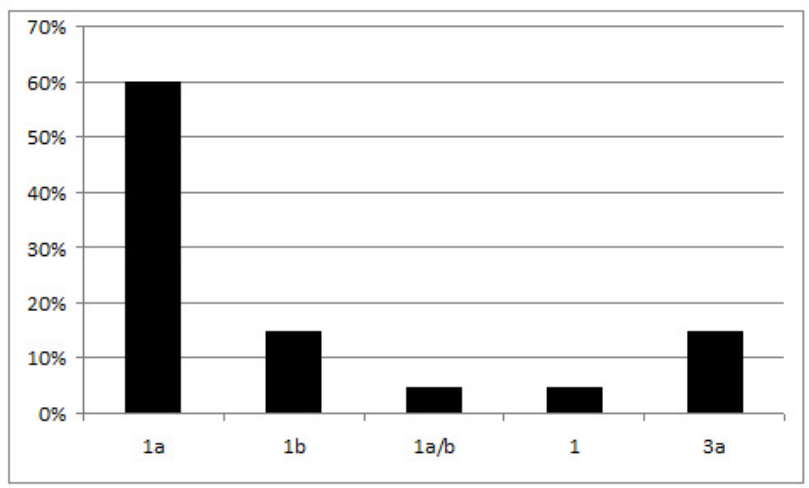

Figure 1. Distribution of blood samples obtained from prisoners according to HCV genotypes in Campo Grande, Mato Grosso do Sul state, Brazil, $2010(n=20)$.

in Campo Grande was lower than those found in northwestern Spain (47.9\%), Italy (38\%), Canada (26.1\%), United States (23.1\%), and Ghana (18.7\%) $(9,11,36-38)$. On the other hand, it was similar to values found in Iran (8.1\%), France (4.9\%), and higher than in Venezuela $(1.5 \%)(10,13,39)$.

The higher prevalence among men in Brazil differs from data from Canada, where women had a greater exposure to injecting drugs (37). In the female incarcerated population of Campo Grande, the prevalence of HCV infection is lower than in Butantã Prison in São Paulo (16.2\%) (17). A study carried out in the Central-West region of Brazil found a prevalence of $6.9 \%$ for anti-HCV (95\%CI: 5.2-9.2\%) among drug users, which is similar to the present findings (40). The frequent use of injecting drugs by women was also observed in Thailand (41).

Low education level, lack of knowledge about hepatitis $\mathrm{C}$, multiple arrests and long periods in prison have been identified by other studies as factors associated with higher occurrences of the infection $(9-11,16,17,40)$. The current study found that less than half of the studied population had steady partners, few individuals used condoms on a regular basis and approximately $1 / 5$ of the studied subjects had a history of homosexual relationship. Although hepatitis C presents low sexual transmission rate, all these factors are connected with high exposure to other STDs $(9-11,16,19,39)$.

The prevalence of $\mathrm{HCV}$ was significantly higher among individuals who received blood transfusions and derivates as described in Venezuela in a period prior to 1994 (13).
Tattooing was significantly higher in anti-HCV positive groups, which agrees with previous research $(10,11,18)$. Despite these other factors, the highest prevalence of hepatitis $\mathrm{C}$ in prisons is related to injecting drug use, which was clear in both the bivariate and multivariate analyses, as described in other studies $(7,13,16,18,36$ 39). The prevalence of anti-HCV was higher among older individuals, which was most probably due to risky behaviors throughout life, a fact observed in Campo Grande and in other incarcerated populations and groups of injecting drug users $(11,37,40)$. The use of injecting drugs and tattooing was not significantly higher among blood donors with hepatitis $\mathrm{C}$, probably due to the peculiarities of this population (42).

In the present study, from a total of 29 subjects who underwent testing for HCV RNA, 20 were positive, showing a viremia of $69 \%$, which was lower than values found in injecting drug users in the Central-West region of Brazil (85.4\%) and in individuals from Belo Horizonte, Minas Gerais state $(98.6 \%)(40,43)$. Such finding agrees with the rate of viremia found in the Northeast region of the country (65.4\%) (30).

Genotypes 1 and 3 are more prevalent in Brazil (24-31, 40, 43). The high frequency of genotype 1 and its subtypes was reported among injecting drug users, blood donors, hemophilic persons and patients subjected to hemodialisys $(26,40$, 43). In the current work, the subtype la was more common, similarly to other studies in the CentralWest region, which differs from studies with equivalent subtypes $1 \mathrm{a}$ and $1 \mathrm{~b}$ or predominance of $1 \mathrm{~b}(27,29-31,40,43)$. The finding of mixed genotype $1 \mathrm{a} / \mathrm{b}(5 \%)$ has been described and may indicate a re-infection by different genotypes (27, $30,43)$.

The rate of co-infection of HIV and HCV was high $(33.3 \%)$ and can be attributed to common factors associated with the risks of these types of infections, such as injecting drug behavior and tattooing $(36,37)$. Among co-infected patients, only HCV genotype 1 was isolated in the present study, which differs from another work that reported the association of genotype 3 with coinfection and injecting drug users (44).

Finally, the current findings demonstrate that early diagnosis, prevention programs and therapeutic interventions are necessary in order to minimize risks involved in the epidemic spread of HCV inside prison systems. 


\section{ACKNOWLEDGEMENTS}

We are thankful to Manoel de Barros Foundation and The United Nations Educational, Scientific and Cultural Organization (UNESCO) for the financial support.

\section{COPYRIGHT}

(c) CEVAP 2011

\section{SUBMISSION STATUS}

Received: February 1, 2011.

Accepted: April 12, 2011.

Abstract published online: April 12, 2011.

Full paper published online: May 31, 2011.

\section{CONFLICTS OF INTEREST}

There is no conflict.

\section{FINANCIAL SOURCE}

Manoel de Barros Foundation and UNESCO provided the financial grants.

\section{ETHICS COMMITTEE APPROVAL}

The present study was approved by the Research Ethics Committee of Federal University of Mato Grosso do Sul (CEP/UFMS) under the protocol number 1461/09. Moreover, all subjects included in the present research signed an informed consent form.

\section{CORRESPONDENCE TO}

MAURÍCIO ANTONIO POMPILIO, rua Tricordiano, 496, Campo Grande, MS, 79051150, Brasil. Phone: +55673026 8715. Fax: +5567 3026 8715. Email: mapompilio@yahoo.com.br.

\section{REFERENCES}

1. Lavanchy D. The global burden of hepatitis C. Liver Int. 2009;29(1):74-81.

2. Singh NK. HIV in prison and consequences outside: the butterfly effect. Sex Transm Dis. 2007;34(2):113-9.

3. Dolan K, Kite B, Black E, Aceijas C, Stimson GV, et al. HIV in prison in low-income and middle-income countries. Lancet Infect Dis. 2007;7(1):32-41.

4. Jürgens R. Dublin Declaration on HIV/AIDS in prisons launched. Can HIV AIDS Policy Law Rev. 2004;9(1):40.

5. Lopes F, Latorre MR, Campos Pignatari AC, Buchalla CM. HIV, HPV, and syphilis prevalence in a women's penitentiary in the city of São Paulo, 1997-1998. Cad Saúde Pública. 2001;17(6):1473-80.

6. Alter MJ. Epidemiology of hepatitis C. Hepatology. 1997;26:S62-S5

7. Burattini MN, Massad E, Rozman M, Azevedo
RS, Carvalho HB. Correlation between HIV and $\mathrm{HCV}$ in Brazilian prisoners: evidence for parenteral transmission inside prison. Rev Saúde Públ. 2000;34(5):431-6.

8. Awofeso N. Prisons as social determinants of hepatitis $\mathrm{C}$ virus and tuberculosis infections. Public Health Reports. 2010;125(4):25-33.

9. Adjei AA, Armah HB, Gbagbo F, Ampofo W, Boamah I, Adu-Gyamfi C, et al. Correlates of HIV, HBV, HCV and syphilis infections among prison inmates and officers in Ghana: a national multicenter study. BMC Infect Dis. 2008;8:33.

10. Azarkar Z, Sharifzadeh G. Evaluation of the prevalence of hepatitis B, hepatitis C, and HIV in inmates with drug-related convictions in Birjand, Iran in 2008. Hepat Mon. 2010;10(1):26-30.

11. Sanchez VM, Castro VF, Alvarez JRP, Herrero LEA, Honorato MA, Gonzalez MJC, et al. Seroprevalence of hepatitis $\mathrm{C}$ virus infection at the time of entry to prison in the prison population in the north-east of Spain. Rev Esp Salud Publica. 1998;72(1):43-51.

12. Sabbatani S, Giuliani R, Manfredi R. Combined pegylated interferon and ribavirin for the management of chronic hepatitis $\mathrm{C}$ in a prison setting. Braz J Infect Dis. 2006;10(4):274-8.

13. Monsalve-Castillo F, Chacín-Bonilla L, Atencio RJ, Porto LD, Costa-Léon LA, Estévez JE, et al. Low prevalence of hepatitis $\mathrm{C}$ virus infection in a prisoner population from Maracaibo, Venezuela. Biomedica. 2009;29(4):647-52.

14. Brasil. Ministério da Saúde. Secretaria de Vigilância em Saúde. Departamento de Vigilância Epidemiológica. Hepatites virais: o Brasil está atento. 3. ed. Brasília: Ministério da Saúde; 2008.

15. Catalan-Soares BC, Almeida RT, Carneiro-Proietti AB. Prevalence of HIV-1/2, HTLV-I/II, hepatitis B virus (HBV), hepatitis $\mathrm{C}$ virus (HCV), Treponema pallidum and Trypanosoma cruzi among prison inmates at Manhuaçu, Minas Gerais State, Brazil. Rev Soc Bras Med Trop. 2000;33(1):27-30.

16. Guimarães T, Granato CF, Varella D, Ferraz ML, Castelo A, Kallás EG. High prevalence of hepatitis C infection in a Brazilian prison: identification of risk factors for infection. Braz J Infect Dis. 2001;5(3):1118.

17. Strazza L, Massad E, Azevedo RS, Carvalho HB. Behavior associated with HIV and HCV infection in female prison inmates in São Paulo, Brazil. Cad Saúde Pública. 2007;23(1):197-205.

18. Coelho HC, de Oliveira SAN, Miguel JC, Oliveira Mde, Figueiredo JF, Perdoná GC, et al. Predictive markers for hepatitis C virus infection among Brazilian inmates. Rev Soc Bras Med Trop. 2009;42(4):369-72.

19. Fialho M, Messias M, Page-Shafer K, Farre L, Schmalb M, Pedral-Sampaio D, et al. Prevalence and risk of blood-borne and sexually transmitted viral infections in incarcerated youth in Salvador, Brazil: opportunity and obligation for intervention. AIDS Behav. 2008;12(4):S17-24.

20. Simmonds P, Bukh J, Combet C, Deléage G, Enomoto $\mathrm{N}$, Feinstone $\mathrm{S}$, et al. Consensus proposals for a unified 
system of nomenclature of hepatitis $\mathrm{C}$ virus genotypes. Hepatology. 2005;42(4):962-73.

21. McOmish F, Yap PL, Dow BC, Follett EAC, Seed C, Keller AJ, et al. Geographical distribution of hepatitis- $C$ virus genotypes in blood-donors: an international collaborative survey. J Clin Microbiol. 1994;32(4):884-92.

22. Mellor J, Holmes EC, Jarvis LM, Yap PL, Simmonds $\mathrm{P}$, Conradie JD, et al. Investigation of the pattern of hepatitis-C virus sequence diversity in different geographical regions: implications for virus classification. J Gen Vir. 1995;76(Pt 10):2493-507.

23. Nainan OV, Alter MJ, Kruszon-Moran D, Gao FX, Xia GL, McQuillan G, et al. Hepatitis C virus genotypes and viral concentrations in participants of a general population survey in the United States. Gastroenterology. 2006;131(2):478-84.

24. Busek S, Oliveira G. Molecular epidemiology of the hepatitis $\mathrm{C}$ virus in Brazil. Genet Mol Res. 2003;2(1):117-23.

25. Campiotto S, Pinho JRR, Carrilho FJ, Da Silva LC, Souto FJD, Spinelli V, et al. Geographic distribution of hepatitis $\mathrm{C}$ virus genotypes in Brazil. Braz J Med Biol Res. 2005;38(1):41-9.

26. Oliveira ML, Bastos FI, Sabino RR, Paetzol U, Schereier E, et al. Distribution of $\mathrm{HCV}$ genotypes among different exposure categories in Brazil. Braz J Med Biol Res. 1999;32(2):279-82.

27. Bassit L, Ribeiro-Dos-Santos G, Da Silva LC, Takei K, Villaca P, David-Neto E, et al. Genotype distributions of hepatitis C virus in São Paulo, Brazil: rare subtype found. Hepatology. 1999;29(3):994-5.

28. Krug LP, Lunge VR, Ikuta N, Fonseca AS, Cheinquer H, Ozaki LS, et al. Hepatitis C virus genotypes in Southern Brazil. Braz J Med Biol Res. 1996;29(12):1629-32.

29. Martins RM, Teles SA, Freitas NR, Motta-Castro AR, Souto FJ, Mussi A, et al. Distribution of hepatitis $\mathrm{C}$ virus genotypes among blood donors from midwest region of Brazil. Rev Inst Med Trop São Paulo. 2006;48(1):53-5.

30. Silva LK, Paraná R, Souza SP, Berby F, Kay A, Trepó $\mathrm{C}$, et al. Hepatitis $\mathrm{C}$ virus genotypes in a northeastern area of Brazil. Am J Trop Med Hyg. 2000;62(2):257-60.

31. Lampe E, Espirito-Santo MP, Martins RM, Bello G. Epidemic history of Hepatitis C virus in Brazil. Infect Genet Evol. 2010;10(7):886-95.

32. Ginabreda MG, Yoshida CF, Niel C. Genomic characterization of Brazilian hepatitis Cvirus genotypes 1a and 1b. Braz J Med Biol Res. 1997;30(3):339-45.

33. Sandres-Sauné K, Deny P, Pasquier C, Thibaut V, Duverlie G, Izopet J. Determining hepatitis C genotype by analyzing the sequence of the NS5b region. J Virol Methods. 2003;109(2):187-93.
34. Focaccia R, da Conceição OJ, Sette H, Sabino E, Bassit L, Nitrini DR, et al. Estimated prevalence of viral hepatitis in the general population of the municipality of São Paulo, measured by a serologic survey of a stratified, randomized and residence-based population. Braz J Infect Dis. 1998;2(6):269-84.

35. Zarife MA, Silva LK, Silva MB, Lopes GB, Barreto ML, Teixeira M da G, et al. Prevalence of hepatitis $C$ virus infection in north-eastern Brazil: a population-based study. Trans R Soc Trop Med Hyg. 2006;100(7):663-8.

36. Babudieri S, Longo B, Sarmati L, Starnini G, Dori L, Suligoi B, et al. Correlates of HIV, HBV, and HCV infections in a prison inmate population: results from a multicentre study in Italy. J Med Virol. 2005;76(3):3117.

37. De P, Connor N, Bouchard F, Sutherland D. HIV and hepatitis $\mathrm{C}$ virus testing and seropositivity rates in Canadian federal penitentiaries: A critical opportunity for care and prevention. Can J Infect Dis Med Microbiol. 2004;15(4):221-5.

38. Macalino GE, Vlahov D, Sanford-Colby S, Patel S, Sabin K, Salas C, et al. Prevalence and incidence of $\mathrm{HIV}$, hepatitis $\mathrm{B}$ virus, and hepatitis $\mathrm{C}$ virus infections among males in Rhode Island prisons. Am J Public Health. 2004;94(7):1218-23.

39. Verneuil L, Vidal JS, Ze Bekolo R, Vabret A, Petitjean $J$, Leclercq $R$, et al. Prevalence and risk factors of the whole spectrum of sexually transmitted diseases in male incoming prisoners in France. Eur J Clin Microbiol Infect Dis. 2009;28(4):409-13.

40. Lopes CL, Teles SA, Espírito-Santo MP, Lampe E, Rodrigues FP, Motta-Castro AR, et al. Prevalence, risk factors and genotypes of hepatitis $\mathrm{C}$ virus infection among drug users, Central-Western Brazil. Rev Saúde Públ. 2009;43(1):43-50.

41. Hayashi K, Milloy MJ, Fairbairn N, Kaplan K, Suwannawong P, Lai C, et al. Incarceration experiences among a community-recruited sample of injection drug users in Bangkok, Thailand. BMC Public Health. 2009;9:492-.

42. Felippe MJDB, Meira DA. Comparison of risk factors among blood donors, volunteers and replacement individuals, infected or not by hepatitis C virus. J Venom Anim Toxins incl Trop Dis. 2009;15(1):103-24.

43. Perone C, Del Castillo DM, Pereira GL, Carvalho Nde O, Januário JN, Teixeira R. High prevalence of genotype 1 in individuals with hepatitis C in Belo Horizonte, MG. Rev Soc Bras Med Trop. 2008;41(3):238-42.

44. Mendes-Correa MC, Cavalheiro NP, Mello C, Barone AA, Gianini RJ. Genotypic distribution of hepatitis C among hepatitis $\mathrm{C}$ and HIV co-infected patients in Brazil. Int J STD AIDS. 2008;19(9):595-9. 